THE PHILOSOPHER'S DESIRE 



\section{THE PHILOSOPHER'S DESIRE}

Psychoanalysis, Interpretation, and Truth

William Egginton

STANFORD UNIVERSITY PRESS

STANFORD, CALIFORNIA

2007 
Stanford University Press

Stanford, California

(C) 2007 by the Board of Trustees of the Leland Stanford Junior University. All rights reserved. No part of this book may be reproduced or transmitted in any form or by any means, electronic or mechanical, including photocopying and recording, or in any information storage or retrieval system without the prior written permission of Stanford University Press.

\section{Library of Congress Cataloging-in-Publication Data}

Egginton, William, 1969-

The philosopher's desire : psychoanalysis, interpretation, and truth / William Egginton.

p. $\mathrm{cm}$.

Includes bibliographical references and index.

ISBN 978-0-8047-5599-3 (cloth : alk. paper)

ISBN 978-0-8047-5600-6 (pbk. : alk. paper)

I. Psychoanalysis and philosophy. 2. Hermeneutics. I. Title.

BFI75.4.P45 442007

I50.19'5- $\mathrm{dc22}$

2007001245

Typeset by Westchester Book Group in II/13.5 Garamond 